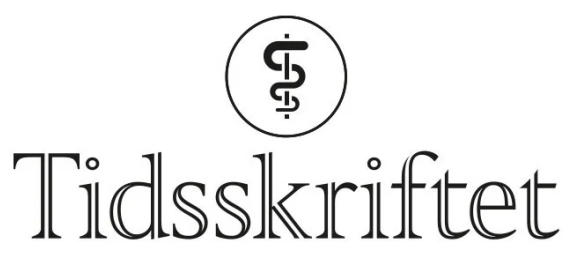

DEN NORSKE LEGEFORENING

\title{
Rettelse: Tallenes aborttale
}

\author{
RETTELSE
}

RAGNHILD ØRSTAVIK

Tidsskr Nor Legeforen 2021; 141: 809.

I Tidsskriftet nr. 9/2021, s. 809 skal referanse 3 være: Østborg TB. Den ubehagelige abortnemnda. Vårt Land 11.3.2021.

Vi beklager feilen, den er rettet på nett.

Publisert: 21. juni 2021. Tidsskr Nor Legeforen. DOI: 10.4045/tidsskr.21.0484

(C) Tidsskrift for Den norske legeforening 2023. Lastet ned fra tidsskriftet.no 26. april 2023. 